\title{
PROFESSIONAL ACTIVITIES
}

(1930-1981) OF LATVIAN-BORN

LITHUANIAN ARCHITECT AND

ENGINEER KAROLIS REISONAS

(1894-1981) IN KAUNAS, PANEVĖŽYS AND ADELAIDE CITIES

\author{
SIGITAS VLADAS SALADŽINSKAS* \\ Lithuanian Society for Engineering Graphics and Geometry \\ (Vilnius, Lithuania) \\ KRISTINA VAISVALAVIČIENĖ \\ Vytautas Magnus University (Kaunas, Lithuania)
}

\begin{abstract}
Summary. The article introduces the professional activities of Latvian-born Lithuanian architect and engineer Karolis Reisonas (in Latvian: Kärlis Reisons; 1894-1981) in the second half of his life - from 1930 in Kaunas, Panevéžys and Adelaide cities - and his role in the history of Lithuanian architecture. K. Reisonas was one of the most prominent creators of modern 20th-century interwar Lithuanian architecture and together with other famous Lithuanian architects formed a special style of Kaunas modern architecture in interwar period. K. Reisonas is the author or co-author of representative buildings in Šiauliai, Kaunas and other Lithuanian cities, as well as in Riga and Adelaide cities. Architect and engineer K. Reisonas worked as Šiauliai City Engineer and Head of Municipal Construction Department (1922-1930), Director of Šiauliai Vocational School (1926), Consultant of Lithuanian Chamber of Agriculture (1927-1928), Head of Construction Department of Kaunas Municipality (19301938), Panevéžys City Engineer (1940) and Burgomaster (1941-1944). From 1949, the Reisonas family lived in Adelaide city, Australia.

To his projects three monuments of independence were built in Lithuania - Monument of Independence in Šiauliai city, Podium of the Freedom Monument of Kaunas city and Roman Catholic Christ's Resurrection Church in Kaunas city. Fourteen of buildings in Lithuania (in Kaunas and Šiauliai cities) designed by him are included in the list of cultural values of Lithuania. Early K. Reisonas' projects

* Corresponding author.

E-mail: kristina.vaisvalaviciene@vdu.lt
\end{abstract}


are characterized by historism, elements of eclecticism and «brick style», later projects are characterized by austere rationalism, functionalism, adaptation to urban construction and cultural and historical context.

Keywords: Karolis Reisonas, architecture of Lithuania, Kaunas, Panevėžys, Adelaide city.

\section{Introduction}

The aim of the article is to familiarize readers with the professional activities of the Latvian-born Lithuanian architect and engineer Karolis Reisonas from June 1930, when he started to work in Kaunas city. It is a continuation of the scientific article «Professional Activities of Latvianborn Lithuanian Architect and Engineer Karolis Reisonas (1894-1981) in Šiauliai» published in the scientific journal of the Research Centre for Engineering History of Riga Technical University (RTU) (2018/2).

This article introduces $K$. Reisonas' activities in the second half of his life, starting from the summer of 1930, when a Latvian-born Lithuanian architect and engineer moved to Kaunas city. It is hard to imagine the landscape of Kaunas city without the vertical of the bell tower of Christ's Resurrection Church designed by K. Reisonas visible from every point in the city. This Roman Catholic Church is a symbol of national resurrection and was built during the interwar period. When Lithuania regained its independence, the church was given back to the believers. If this project had been the only one in K. Reisonas' professional career, his name would still be included in the history of Kaunas and Lithuanian architecture.

Researching and promoting his works is especially relevant today, as in recent years in Lithuania significant steps have been taken to bring the modern architecture of the interwar period to the UNESCO World Heritage List [1]. Seven objects designed by him were built in Kaunas city and fourteen of buildings in Lithuania designed by him are included in the list of cultural values of Lithuania.

\section{Kaunas - Modern Temporary Capital of Lithuania}

After active administrative and creative work in Šiauliai city, K. Reisonas moved to Kaunas, the temporary capital of Lithuania. For about 20 years, Vilnius and the eastern part of Lithuania were annexed and at that time Kaunas became the administrative centre of Lithuania and began to develop rapidly. K. Reisonas was appointed Head of the Construction Department of Kaunas City on 1 June 1930 and was in the position until February 1938. 
The Kaunas period was the most productive in the architect's biography - he had great opportunities, was commissioned to design important objects and had success in competitions. It was the time when he started applying the principles of functionalism in his work. In 1930, having received the permission form the Bishop of Rome, he married Lithuanian citizen Elena Butnevičiūte [2], Kaunas is also the native city of both K. Reisonas' children - daughter Renata (born in 1931) and son Irvis (born in 1934).

K. Reisonas started to develop the projects for Kaunas city already when living in Šiauliai city. One of the first works - together with an engineer Grigorijus Gumeniukas (1892-1969) - was a project for the modern cinema «Forum» with 700 seats (1929-1930, 46a Laisvés alejja). In 1928, K. Reisonas took part in the competition of project ideas for Christ's Resurrection Church in Kaunas. It was crucial for the architect's life. Although K. Reisonas' project was in the third place in the contest (out of 15 participants), he was invited to continue developing the idea. After a few attempts, the architect presented an impressive project to the commission, which was reminiscent of the inspirations [3] of famous Lithuanian artists Mikalojus Konstantinas Čiurlionis (1875-1911) and Kazys Šmonis (1887-1978). Information about the planned construction of the church was also distributed in Latvia.

Figure 1. The project of Christ's Resurrection Church in Kaunas city (1929) [4].

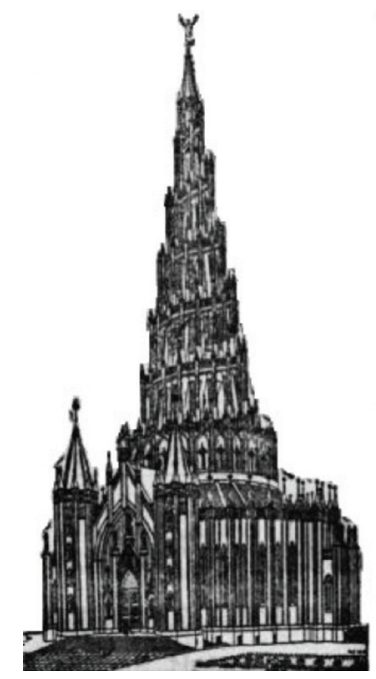

In 1929, newspaper «Lauku Doma» («Country View») and «Vērotājs» («Observer») about the new church wrote: «.. it will be one of the most beautiful buildings in the Baltic States .. it will give the same importance to Kaunas city as does the Eiffel Tower to Paris or the big cathedral in Cologne». It was reported: «.. the church will be 83 meters high and the 
statue of Christ at the top of the tower is going to be seven meters high». It was described as a building of peculiar Gothic style with foundry ornaments that could seat up to 6000 people [5]. Only the surname of the author of the project was mentioned in the article without mentioning that he was of a Latvian nationality. In Lithuania, on the other hand, this fact unfortunately became a rather painful argument of the critics about the architect. Art historian Halina Kairiukštyté-Jaciniene (1896-1984) wrote that the choice of a foreigner as a project developer «hurt national ambitions and ego of Lithuanian architects». The critic noted that the project had the lack of «Lithuanian concept» and artistic quality, the architect belonged to a «wrong» confession, he was erroneously called a reformer and claimed that he was not the right person to «build a Lithuanian Catholic Church» [6].

The project surprised some and irritated others, nevertheless it stimulated public imagination. Initially, the commission approved the project, but soon it was abolished when it became clear that the construction of such a church would cost too much for Lithuania. Nevertheless, the architect did not give up and in 1932, he presented a new project of the church. In 1933, the senior construction inspector confirmed it and the construction began in 1934 [7].

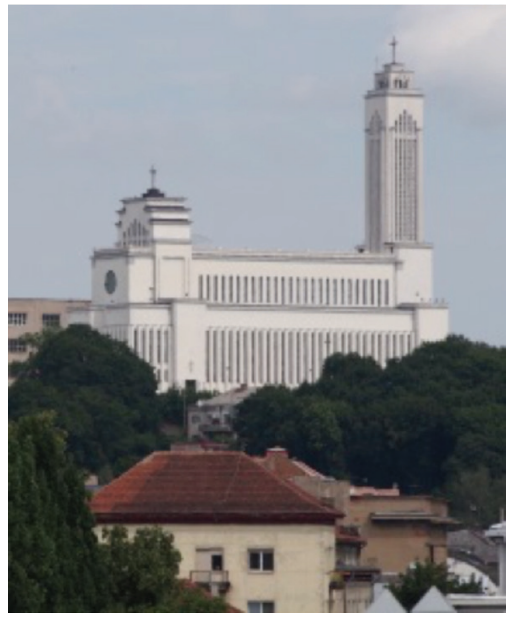

Figure 2. Christ's Resurrection Church in Kaunas (2018) [8].

People donated funds to build this church. Reports on the new building also appeared in the Latvian press. In a special report from Kaunas city in 1936 it was written that «the project harmoniously merges the modern style with the style of the church and the spirit of the monument». The article also mentioned architect's nationality: «.. This building will be one of the most grandiose buildings in the Baltic States and its author is engineer Reisonas of Latvian nationality» [9]. Such content 
was politically handy for promoting the idea of bringing Lithuania and Latvia closer.

K. Reisonas is the only official author of the Resurrection Church project, but it is possible that his colleague, architect Vladimiras Dubeneckis (1888-1932), was also unofficially involved in developing the artistic idea of the building. Doctor of art science Lina Preišegalavičienè, the author of the monograph on the works of $V$. Dubeneckis, recently proposed such a hypothesis. Although $V$. Dubeneckis himself did not take part in the competition of church projects, according to the author of the monograph, judging by the newly founded sketches of the architect, the present church project is undoubtedly the result of cooperation of the two mentioned architects. It is known that such voluntary creative co-operation with $V$. Dubeneckis has also been with other architects in Kaunas city [10].

Christ's Resurrection Church is a three-nave basilica building with a rectangular layout and a flat roof. The central nave is 30 meters high and the lateral - 18 meters. The skyline of the roof of the church and the silhouette of the main facade made of rectangular steps are emphasized by the vertical lines of rhythmic narrow windows and the 70-meter high tower with a cross. The monumentality of the building is also reinforced by the chosen place - the church was built on the high bank of the Neman river valley, behind the facades of other buildings, so the church seems even bigger from the city centre than it is in reality. It is possible that the author was inspired to design such form of building, which expresses great national ambitions, by the monumental architectural tendencies that reached Lithuania from the West. Reviewing the press of that time, the similarity of the silhouette of this church with New York's new skyscrapers can be seen, whose photos were frequently published in newspaper «Naujas Žodis» («New Word») from 1928 [11; 12] and in other Lithuanian editions.

Figure 3. Skyscraper in America (1928) [13].

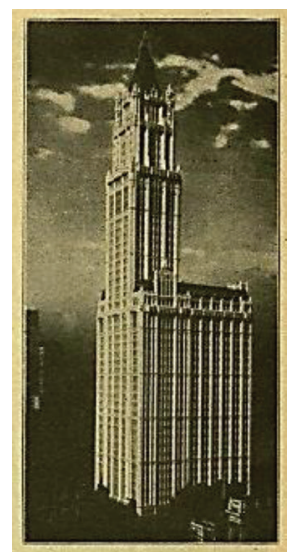

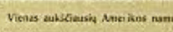

Professional

Activities

(1930-1981)

of Latvian-born

Lithuanian

Architect and

Engineer

Karolis Reisonas

(1894-1981) in

Kaunas, Panevèžys

and Adelaide cities 
Lithuanians admired Americans, the skyscrapers were called monuments of progress, their idealized image fascinated the visionaries of modern city. At the end of the 1930s, the City Council even banned the construction of buildings that are higher than six floors without a special permission to compete with the most important symbolic city dominant [14]. In the 1930s, it was also said in Latvia that «the Baltic States are experiencing an era of monumental building» [15], but the tendency of projects presented at the Riga Architectural Exhibition in 1939 - to «show off with other overpowering towers» - was strongly criticized [16].

Architectural historian J. Kančienè believes that «the church project reflects the potential of a new era - its aesthetic ideals, the technology of construction» [17]. The church was built on 900 reinforced concrete piles [18] that were driven into a floating sand ground. It is known that K. Reisonas wanted to publish a textbook about this construction technology [19]. Technical supervision of the construction was carried out by the author of the project. The construction continued until June 1940, when it was interrupted by the Soviet occupation and after that World War II. After the war, the building was nationalized, renovated, divided into several floors and made suitable for the needs of the radio factory. The Church was returned to the believers only in 1989. Its renewal required great effort from specialists and society. The church had a second consecration in 2004.

The main facade of the Resurrection Church has stylistic similarities with other sacral buildings designed by K. Reisonas. The Kaunas Evangelical Reformed Church (1937, 41 E. Ožeškienès gatvė) was also built in a similarly modern style of architecture and was often referred to as the «Little Church of the Resurrection».

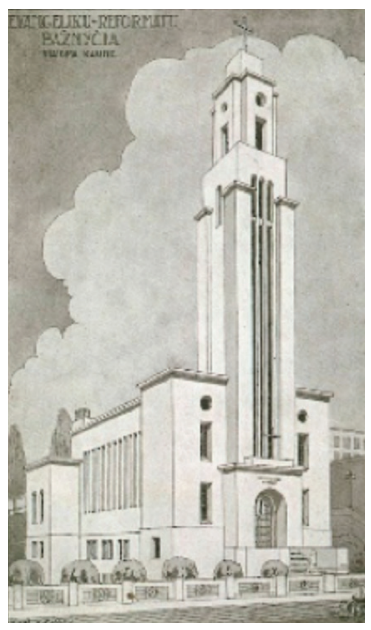

Figure 4. Kaunas

Evangelical Reformed Church: Postcard «Evangeliku-reformatu bažnyčia statoma Kaune». Miškinis, A., Morkūnas, K. Kauno atvirukai. 1918-1940 [20].

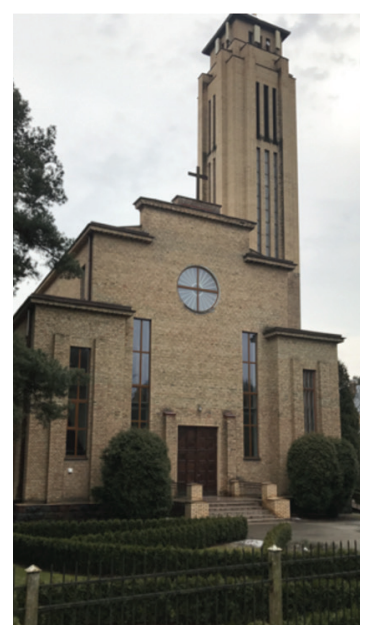

Figure 5. Christ the King Church in Riga (2018) [21]. 
The construction of the church was not completed until World War II, in the Soviet times, it was renovated, turned into a warehouse, used for various city needs and until now the reformed church has been only partially restored, the building still lacks the top of the tower.

In addition to this modern architectural group of sacral buildings, one can also mention Christ the King Church in Riga (1934-1935, 86 Meža prospekts) - the only known $K$. Reisonas' project in his native Latvia.

In Lithuania, false information has been spread about the fact that the project of Roman Catholic Church developed by K. Reisonas together with the famous Latvian architect Indrikis Blankenburgs (1887-1944) has not been realized [22; 23]. The mistake could have appeared because the information was originally searched on St. Joseph's Church, because it was not known that after the development of the church project the plot of land and congregation was changed. At first, it was planned to build the church at St. Joseph's Congregation, but in 1930, another plot was given to the church, but in 1937, its original name was changed to Christ the King Church. Although there were various failures during the construction works of the church (poor concreting of church foundations) and corrections in the project (engineer A. Strazdinš), its fate was not as dramatic as of the already mentioned churches in Kaunas city. The church was consecrated in 1943 and is still operating. The opening of a new Roman Catholic Church during World War II was almost equalled to a miracle in the Latvian press [24]. In the 1960s, the church was renovated (chapel built, interior reconstructed) [25], but its external architectural style remained unchanged, even on the contrary - in 2003-2004, to the original project the construction of the church bell tower was completed [26] and the church obtained the original silhouette designed by its authors.

Christ's Resurrection Church in Kaunas served a sample for the project of St. Ignatius of the Loyola Catholic Church in Akniste town, which was a reduced version of the original plan, the construction of which started in 1937 (architect - Pāvils Pavlovs; 1882-1977) [27]. The church in Akniste was completed in 1940 and, like Christ the King Church in Riga, is very similar to the church in Kaunas, designed by K. Reisonas.

Compositional similarities can also be seen in the Monument of Independence of Šiauliai city and in the Podium of the Freedom Monument of Kaunas city designed by K. Reisonas. It was supposed to be rebuilt when the old monument decorated by the allegorical statue of the Angel of Freedom (sculptor Juozas Zikaras (1881-1944), architect V. Dubeneckis) was moved to another place. In 1936, K. Reisonas as a co-author of the building of the new Vytautas the Great War Museum, was entrusted with reorganization of the adjacent square [28]. The relocated and restored monument was harmoniously integrated into the context of the Unity
Professional

Activities

(1930-1981)

of Latvian-born

Lithuanian

Architect and

Engineer

Karolis Reisonas

(1894-1981) in

Kaunas, Panevèžys

and Adelaide cities 
Square and its vertical rhythmically repeated the vertical of the museum bell tower designed by K. Reisonas.

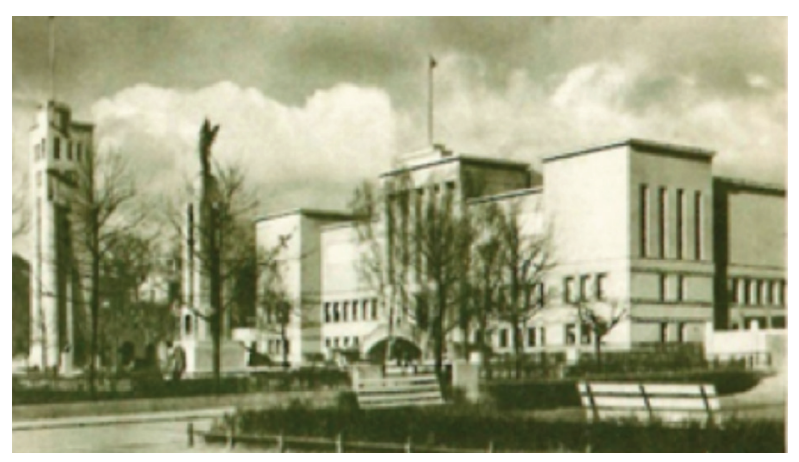

Figure 6. Postcard «Kaunas. Vytauto Didžiojo muziejus» (photo V. Augustins). Miškinis, A., Morkūnas, K. Kauno atvirukai. 1918-1940 [29].

Later it was also supplemented by the tower of Christ's Resurrection Church in Kaunas, rising on the hill near the Unity Square. During the Soviet era, the monument was demolished (1950), but the statue was kept in the collection of the M. K. Čiurlionis National Art Museum. In 1989, the monument returned to its old place (the author of the reconstruction of the podium was architect Algimantas Antanas Sprindys; 1928-2018).

In Kaunas, K. Reisonas realized about 20 projects. The aforementioned Vytautas the Great War Museum, which was built in the city centre (1931-1936, 64 K. Donelaičio gatvè), is an example of a conformable creative collaboration of the architects. The author of the idea of the artistic composition of the object was V. Dubeneckis, Kazimieras Kriščiukaitis (1870-1949) was responsible for the planning. K. Reisonas was entrusted with the calculation of structures and organization of construction. The project was still under development during the construction. Stasys Kudokas (1898-1988), Vsevolodas Kopylovas (1902-?) and Bronius Elsbergas (1901-1998) helped to work out the details of the project [30].

$K$. Reisonas implemented his own artistic ideas in the projects of the Land Bank (1934-1935, 73 K. Donelaičio gatvé), which was built next to Vytautas the Great War Museum on the opposite side of the street.

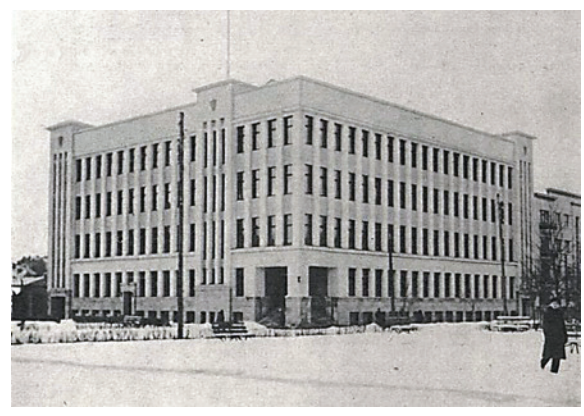

Figure 7. The building of Land Bank in Kaunas (1935) [31]. 
The functionalist building was masterfully integrated in the urban context and completed the landscape of the Unity Square. The interplay of horizontal and vertical architectural lines created the impression of lightness and elegance of the buildings in the new representative city centre. This method also influenced and inspired other modern urban builders and created a special urban face.

In Kaunas K. Reisonas collaborated with famous Lithuanian architect, former student of Riga Polytechnic Institute Vytautas LandsbergisŽemkalnis (1893-1993). One of their their joint works is the project of the office of the Milk Processors' Union «Pieno centras» (1932-1934, 55 Laisvés aleja). The author of the artistic idea of the building was V. Landsbergis-Žemkalnis. In 1937, at «Exposition Internationale des Arts et des Techniques» in Paris the project was awarded an Honorary Diploma and Medal.

Other administrative buildings designed by the architect in Kaunas also have an important place in architecture and cultural history. Although the eclectic features of the Šiauliai period (symmetry, decorative details, arches) [32] of the front facade of the Lithuanian Agricultural Cooperative Union «Lietūkis» office and residential building (1930, 43 Vytauto prospektas) can be traced, the end facade surprises with modern and a functional project solution that allowed to increase the mass of the building and to install fine loggias on the upper floors. $K$. Reisonas lived in this house and it is evidenced by the memorial plaque on it (1994, sculptor Leonas Strioga).

The features of modern architecture can be seen in the House of the Chamber of Agriculture (1933-1934, 2 K. Donelaičio gatve) with typical Art Deco features - a rounded front of the eastern corner and a vertical east-facing facade that is creatively suited to the curve of the adjacent street.

K. Reisonas faced a difficult situation when he was designing the Rectorate Building of the Catholic Priests' Seminar (1933-1934, 21 Rotušes aikšte) and an exclusive Archbishop's Residence (1935, 14a Rotušes aikšte) decorated with columns, balustrades and decorative vases in the Old Town of Kaunas. The attempt by K. Reisonas to place large-scale buildings in a historically sensitive context is nowadays seen as controversial and criticized by contemporaries, but that does not mean that the architect ignored the principle of architectural harmony. In an interview on the construction of Kaunas city, he emphasized that the context should be taken into consideration when designing new buildings. He said that «every architect is trying to stand out with his works, wants to be different from others, which leads to distorted view of streets. However, sometimes it is not possible to adapt to adjacent buildings as they do
Professional

Activities

(1930-1981)

of Latvian-born

Lithuanian

Architect and

Engineer

Karolis Reisonas

(1894-1981) in

Kaunas, Panevèžys

and Adelaide cities 
not fit into the common view of the street: they are either too low or too old» [33].

K. Reisonas stood out making an altruistic gesture - he designed St. Vincent from Paul's Old People's Shelter without reward, which became famous not only because it was the first modern social care institution in the Republic of Lithuania, but also because the secret Lithuanian Liberation Committee was based there during World War II, which in 1941 organized an uprising against Nazis.

Almost all of the apartment buildings or private houses designed by K. Reisonas are related to Kaunas intellectuals of that time. One of them a well-known Lithuanian poet, a long-time Rector of Kaunas Priests' Seminary, priest Jonas Mačiulis-Maironis (1862-1932) commissioned a house (1931-1932, 9 Amerikos lietuviu gatvé). Unfortunately, the poet did not move to the newly built house, as he died in 1932. K. Reisonas was commissioned to design a monastery building (1939, 1 J. Pabrežos gatvé) on the land of the poet's sister, which she gave to the nuns of St. Elizabeth Sisters' Congregation.

K. Reisonas also designed industrial buildings in Kaunas city. It is known that he was entrusted to design the Kaunas Market Hall. The architect had already worked on the design of this type of buildings in Šiauliai city. In February 1931, he was sent to Riga city «to get acquainted with the construction of the newly built central hall» [34]. Unfortunately, the idea of Kaunas Market Hall was not realized because the city lacked money. The construction of slaughterhouses of agricultural cooperative «Maistas» and other industrial buildings is associated with the name of K. Reisonas. In 1937, there was a dramatic end of the construction of the garages of Kaunas Bus Park in outskirts of Kaunas, Šančiai. During the construction of building, the roof collapsed and one person died. After this accident, K. Reisonas resigned from the Construction Department of Kaunas city and started to work in a private practice [35].

It has not been investigated whether Christ the King Church in Riga is the only object designed by $K$. Reisonas in Latvia, but he has made a great contribution to Lithuanian architecture. In the 1930s, Taurage City Municipal Hospital, Jurbarkas City State Lung Disease Hospital, Solar Gymnasium, Pasvalys High Commercial School, office, elevator and warehouse of Klaipeda Agricultural Cooperative Union «Lietūkis» were built. The authors of the article recently found out that the building of Agricultural Small Credit Bank in Biržai city (1935, 6 Kestučio gatvé) was designed by K. Reisonas. It is a modern two-storey building, the construction which was an important and highly anticipated event in the small town [36]. From the already mentioned unrealized K. Reisonas' projects Marijampole Defender House (Šaulių namai) and others could be mentioned. Virgin Mary's Wooden Church (1938) in Anykščiai town designed by 
K. Reisonas differs from other sacred buildings with the features of both folk and modern architecture.

In addition to the already mentioned original projects, the architect and the engineer also took part in renovation of various buildings (for example, Kaunas Boys' Gymnasium «Aušros», Little Christ's Resurrection Church in Kaunas, the towers of St. Jacob the Apostle Church in Jonava, etc.). The experience of the architect and engineer was also useful in restoring the Lidoki Manor (Ukmergè District), which the Reisonas family bought in 1935. In the manor house, where 105 hectares of sample farming was developed, where mostly stayed K. Reisonas' wife Elena with the children, the architect visited the family on the weekends. According to the local people's memories, after the Reisonas settled in the manor a Lithuanian cultural centre was started there - a school, a library and meetings of intellectuals took place. It is also said that the father of architect $K$. Reisonas, the sea captain Simanis Reisons, who also had an admirable colourful parrot [37], visited the manor.

\section{Emigration. Ideas Continued}

Soviet repression against Lithuanian intelligentsia had an effect also on the fate of Reisonas' family. In order to avoid exile, the former servant of state institutions and a co-owner of the manor, had to leave everything and move to Panevėžys. There he worked as Head of the Construction Department, developed the City Master Plan [38], devoted much attention to the rational arrangement of residential houses and industrial facilities in the newly created areas and to using the Nevéžis River for the development of water sports. From July 1941, K. Reisonas was for three years Burgomaster of Panevéžys city [39], but at the end of World War II he emigrated to Germany with his family.

In 1949, Reisonas family emigrated to Australia. The architect began to work in the Adelaide City Architecture Department, designed the project of Adelaide Lithuanian Community House free of charge, designed private houses for Lithuanian emigrants, was an active member of the Australian Union of Lithuanian Engineers and Architects and held the position of Vice-Chairman of the Board of the Lithuanian Union of Adelaide.

Besides the buildings that were designed for the Adelaide Lithuanian Community, the uniqueness of $K$. Reisonas' work is also evidenced by the neo-byzantine style of Adelaide's Russian Orthodox St. Nicholas Church (1959-1961, 41-42 Greenhill Road, Wayville), built in collaboration with architect Vladimir Sergejevich Pozhidayev (Владимир Сергеевич Пожидаев; 1909-1972) and engineer N. Kovanjko 
(Н. М. Кованько; ?-?) [40]. The main facade of the building is adorned with vertical circular friezes, eclectic details, roofs and towers are characteristic for Russian Orthodox churches. The church's uplifting composition on the side facades gives the building a lightness effect and resembles the composition of the roof chapel window composition similar to Christ's Resurrection Church in Kaunas. There are still other buildings designed by K. Reisonas in Adelaide, for example, it is known that the architect has designed one of the buildings of the Concordia College in Adelaide, but there is a lack of more precise information about it.

For merits to Lithuania K. Reisonas was awarded the 4th Class Order of the Lithuanian Grand Duke Gediminas (1933), the 3rd Class Order of Vytautas the Great (1938) and the Lithuanian Independence Medal, which was founded in 1928 in honour of the 10th anniversary of the Republic of Lithuania.

\section{Conclusions}

K. Reisonas' creative and administrative work can be divided into four periods: Šiauliai (1922-1930), Kaunas (1930-1940), Panevéžys (19401944) and Adelaide (1949-1981). Although the first two are the most creative in terms of architectural heritage, the most important is the Kaunas period. $70 \%$ of the buildings built during this period are included in the list of cultural values of Lithuania. K. Reisonas participated in the creation of important representative Lithuanian buildings of the temporary capital of Lithuania. Together with other famous Lithuanian architects he founded a special modern architecture style of interwar period in Kaunas city. Many of his projects featured functionality, ascetic rationalism, adaptation to the urban and cultural-historical context.

The architect of Latvian origin is the author of three particularly important monuments of independence of Lithuania - Monument of Independence in Šiauliai city, Freedom Monument in Kaunas and the monumental Christ's Resurrection Church in Kaunas. The creative and human spirit of the architect can be traced in Latvia, Lithuania and far away in Adelaide.

Being a highly qualified specialist K. Reisonas also made a major contribution to the development of Lithuanian agricultural construction: he founded and ran the courses of craftsmen and courses in construction and expanded the range of construction workers; his textbooks on agricultural construction were the first of the kind in Lithuanian.

The versatile personality of $K$. Reisonas is well illustrated by his exlibris drawn in 1928 by his friend, Gerardas Bagdonavičius (1901-1986). The centre of it features an outstanding building that emphasizes the 
architect's main goal - to create a project of a monumental building. The drawing depicts tools of an architect, engineer and teacher, from which $K$. Reisonas did not part until the end of his life.

Jonas Lukšé, a researcher, artist and architect of Kaunas historical and architectural heritage, has created a cycle of drawings dedicated to K. Reisonas' work in Kaunas city. Pen-and ink drawing have captured around 20 design objects. The artist draws attention to the fact that they have not only an architectural value - eight of them are included in the list of cultural values of Lithuania, but five have a historic cultural heritage status. In February-March 2018, the works of J. Lukšé, were exhibited in Riga - at the Riga Lithuanian Secondary School and in the Exhibition Hall of RTU Research Centre for Engineering History.

The life and creative work of $K$. Reisonas is evidenced and reminded of not only by the buildings and drawings that have survived to this day, but also by the memorial plaques installed in Kaunas and Šiauliai.

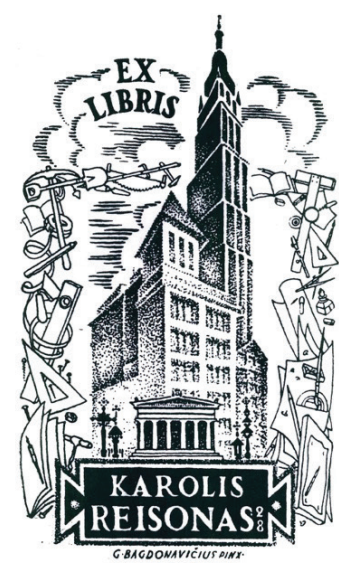

Figure 8. K. Reisonas' exlibris. Author Gerardas Bagdonavičius (1928) [41].

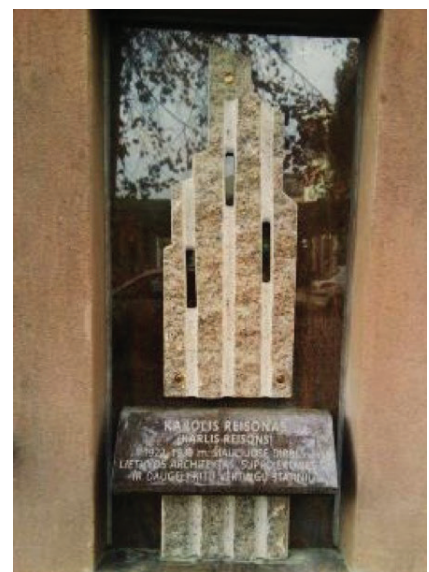

Figure 9. Memorial plaque to Reisonas in Kaunas city (arch. L. Strjoga) [42].

In 2007, a street in Kaunas suburbs was named after K. Reisonas. His works are mentioned in the history of architecture, photo exhibitions, seminars and conferences. K. Reisonas' works are also represented in the database created by the Architectural and Urban Studies Centre of Kaunas University of Technology: www.autc.lt.

\section{LIST OF SOURCES AND LITERATURE}

[1] UNESCO Tentative lists. «Kaunas 1919-1939: The Capital Inspired by the Modern Movement» [online]. http://whc.unesco.org/en/ tentativelists/6166/ [cited: 25.02.2019]. 
[2] Kauno Šv. Kryžiaus RKB Santuokos metrikų knyga, 1930. P. 105, ieraksta Nr. 63.

[3] Jankevičiūtè, G., Petrulis, V. «Tautos šventovè: Prisikèlimo bažnyčia». Optimizmo architektūra: Kauno fenomenas, 1918-1940. Vilnius: Lapas, 2018, p. 94.

[4] Kristus augšāmcelšanās baznīcas projekts (1929). Lauku Doma, 1929 gada 31. oktobris, Nr. 40, 3. lpp.

[5] Kristīgas tautas brīvības piemineklis. Vērotājs, 1929. gada 9. novembris, Nr. 39, 1.-2. lpp.

[6] Kairiukštytė-Jacinienė, H. Prisikèlimo bažnyčios reikalu. Lietuvos Aidas, 1930, Nr. 55, p. 2.

[7] Buškevičienè, A. Prisikèlimas. Kaunas: Judex, 2006, Nr. 42.-44., p. 102.

[8] Kristus Augšāmcelšanās baznīca Kauṇā. R. Vaisvalavičus foto, 2018.

[9] Lietuvas Augšāmcelšanās baznīcas projekta autors - latvietis. Jaunākās Zinnas, 1936. gada 26. augusts, Nr. 193, 16. lpp.

[10] Preišegalavičienè, L. Tautinès modernybės architektas: Vladimiro Dubeneckio gyvenimas ir kūryba 1888-1932. Kaunas: Nacionalinis M. K. Čiurlionio dailès muziejus. 2018, p. 162-163.

[11] Fotoattēls «Vienas aukščiausių Amerikos namų». Naujas Žodis, 1928, Nr. 10-11, p. 18.

[12] Fotoattēls «Naujas dangorèžis». Naujas Žodis, 1930, Nr. 2, p. 38.

[13] Amerikas debesskrāpja fotoattēls. Naujas Žodis, 1928, Nr. 23-24, p. 15.

[14] Laurinaitis, P. T. «Futuristinès Kauno vizijos». Optimizmo architektūra: Kauno fenomenas, 1918-1940. Lapas, 2018, p. 68.

[15] Baltijas valstis piedzīvo monumentālu celtnu radīšanas laikmetu: Saruna ar Rīgas pilsētas galvu R. Liepiṇu. Brīvā Zeme, 1937. gada 17. jūnijs, Nr. 133, 6. lpp.

[16] Rutmanis, J. Celtniecības izstāde. Latvijas Arhitektūra, 1939, Nr. 6, 168. lpp.

[17] Kančienė, J. Architektas Karolis Reisonas. Kaunas: Geltona, [b. m.], p. 5.

[18] Kančienė, J. «Prisikèlimo bažnyčia». Kauno architektūra. Vilnius: Mokslas, 1991, p. 351.

[19] KRVA, 219. f., 3. apr., 508. 1., 27. lp.

[20] Kauṇas Evangélisko reformātu baznīca: a) Atklātne «Evangelikųreformatų bažnyčia statoma Kaune». Miškinis, A., Morkūnas, K. Kauno atvirukai. 1918-1940: Katalogs. Vilnius: Lietuvos nacionalinis muziejus, 2001, p. 152-153.

[21] Kristus Karaḷa baznīca Rīgā. Foto Kristupas Saladžinskas, 2018.

[22] Kančienè, J. Architektas Karolis Reisonas. Kaunas: Geltona, [b. m.], p. 16.

[23] Jankevičiūtė, G., Petrulis, V. «Tautos šventovè: Prisikèlimo bažnyčia». Optimizmo architektūra: Kauno fenomenas, 1918-1940. Lapas, 2018, p. 96.

[24] Katoḷu dievnama jaunceltne Rīgā. Daugavas Vēstnesis, 1943. gada 20. aprīlis, Nr. 93, 4. lpp.

[25] Rīgas Kristus karaḷa draudze [tiešsaiste]. http://karalis.lv/vest ure\#1500533251709-61119636-2524 [skatīts: 03.11.2018]. 
[26] Levina, M., Zilgalvis, J., Tipāne, A., Čoldere, D., Banga, V. The Heritage of Religious Architecture and Art in Riga. Rìga: Neputns, 2010, 426. lpp.

[27] Aknīstes sv. Ignācija no Lojolas katoḷu baznīca [tiešsaiste]. http://www. akniste.lv/?id=399\&lang=lv [skatīts: 03.11.2018].

[28] Jankevičiūtè, G., Petrulis, V. «Nacionalinè tapatybė: Vytauto Didžiojo muziejus». Optimizmo architektūra: Kauno fenomenas. 1918-1940. Vilnius: Lapas, 2018, p. 86.

[29] Atklātne «Kaunas. Vytauto Didžiojo muziejus» (foto V. Augustins). Miškinis, A., Morkūnas, K. Kauno atvirukai. 1918-1940. Katalogas. Vilnius: Lietuvos nacionalinis muziejus, 2001, p. 87.

[30] Kančienė, J. «Vytauto Didžiojo muziejus». Kauno architektūra. Sast. A. Jankevičienè. Vilnius: Mokslas, 1991, p. 306.

[31] Zemes bankas ēka Kauṇā. Technika ir ūkis, 1935, Nr. 1, 26. lpp.

[32] Baužienè, M. Didžiausio Lietuvos nepriklausomybės dešimtmečio paminklo autorius. Žemaičiu Žemé. 2007, Nr. 4, p. 47.

[33] Kauno miesto privati statyba: pasikalbèjimas su miesto inžinieriumi K. Reisonu. Lietuvos Aidas, 1934, Nr. 69, p. 8.

[34] Kauno miesto halès. Lietuvos Žinios, 02.02.1931, p. 8.

[35] KRVA, 219. f., 3. apr., 508. lieta, 9. lp.

[36] Žk. Ilgų metų kruopštaus darbo dideli vaisiai. Ūkininko Patarejjas, 1936, Nr. 3, p. 13.

[37] Gailiūnaitè, O. Eleną Butnevičiūtę-Reisonienę prisimenant. Moteris: Lietuvių Moterų Kanadoje Žurnalas. 1985-1986, p. 18.

[38] Reisonas, K. Miesto statybos darbai ir planai. Panevéžio Tiesa, 1940., Nr. 7, p. 4.

[39] Astramskas, A. Miesto vadovai: Panevēžas pilsētas vadītāju saraksts [tiešsaiste]. http://www.panevezys.lt/lt/gyventojams/miestas-216/istorija/ miesto-vadovai.html [skatīts: 02.06.2018].

[40] St. Nicholas Church [online]. http://saintnicholasadelaide.org.au/?page_ $i d=71$ [skatīts: 04.09.2018].

[41] K. Reisona ekslibris. Autors G. Bagdonavičus (1928). Šauḷu muzejs «Aušra», ŠAM D-T 6764.

[42] Memoriālā plāksne K. Reisonam Šauḷos (tēln. K. Bimba). Foto A. Zabitītes (2018).

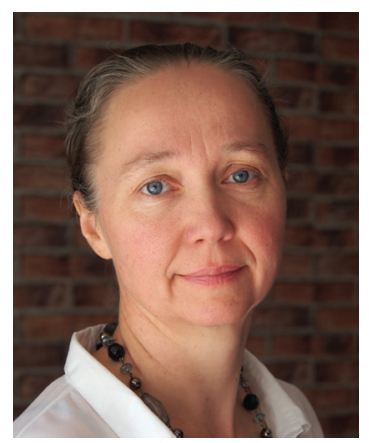

KRISTINA VAISVALAVIČIENĖ, $M g$. philol., is a PhD student of Lithuanian philology at Vytautas Magnus University (Kaunas, Lithuania), administrator of the VMU Centre of Letonics, member of the association «Lietuvos ir Latvijos forumas». Her main academic interests are cultural relations between Lithuania and Latvia, Baltic literature, children's literature and periodicals.

Address: 23 V. Putvinskio gatve 23, Apt. 220, Kaunas, LT-44243, Lithuania.

Phone: +370 61253317

E-mail: kristina.vaisvalaviciene@vdu.lt
Professional

Activities

(1930-1981)

of Latvian-born

Lithuanian

Architect and

Engineer

Karolis Reisonas

(1894-1981) in

Kaunas, Panevèžys and Adelaide cities 


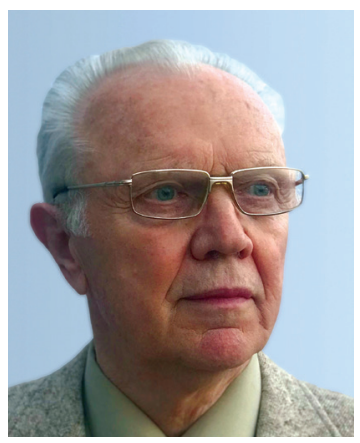

SIGITAS VLADAS SALADŽINSKAS is a specialist of descriptive geometry, researcher of the Lithuanian architecture and culture, member of the Lithuanian Society for Engineering Graphics and Geometry, emeritus expert teacher of mathematics and engineering design, a member of international association BALTGRAF, a member of Lithuanian Society for Engineering Graphics and Geometry. His main academic interests are the methods and development of teaching mathematics and engineering design, the history of architecture of Šiauliai and Panevéžys.

Adress: 30C Žirmūnu gatvé Apt. 8, Vilnius, LT-9229, Lithuania

Phone: +370 64751976

Sigits Vlads Saladžinsks, Kristina Vaisvalavičiene

\section{Latviešu izcelsmes Lietuvas arhitekta un inženiera Kārḷa Reisona (1894-1981) darbība (1930-1981) Kauṇā, Panevēžā un Adelaidā}

Raksts iepazīstina ar latviešu izcelsmes Lietuvas arhitekta un inženiera Kārḷa Reisona (Karolis Reisonas; 1894-1981) profesionālo darbību mūža otrajā pusē - no 1930. gada Kauṇā, Panevēžā un Adelaidā - un viṇa darbu nozīmi Lietuvas arhitektūras vēsturē. K. Reisons bija viens no spilgtākajiem 20. gadsimta starpkaru perioda Lietuvas modernās arhitektūras radītājiem, kopā ar citiem slaveniem Lietuvas arhitektiem veidoja īpašo starpkaru perioda Kauñas modernās arhitektūras stilu. K. Reisons ir reprezentatīvu celtṇu Šauḷos, Kauñā un citās Lietuvas pilsētās, kā arī Rīgā un Adelaidā autors vai līdzautors. Arhitekts un inženieris K. Reisons strādāja par Šauḷu pilsētas inženieri un pašvaldības Būvniecības nodaḷas vadītāju (1922-1930), Šauḷu arodskolas direktoru (1926), Lietuvas Lauksaimniecības kameras konsultantu (1927-1928), Kauṇas pašvaldības Būvniecības nodaḷas vadītāju (1930-1938), Panevēžas inženieri (1940) un birǵermeistaru (1941-1944). No 1949. gada Reisonu ǵimene dzīvoja Adelaidā, Austrālijā.

Pēc viṇa projektiem Lietuvā uzcelti trīs neatkarības pieminekḷi - Šauḷu Neatkarības piemineklis, Kaun,as Brīvības pieminekḷa postaments un Kauñas Romas katoḷu Kristus Augšāmcelšanās baznīca. 14 no viṇa projektētām celtnēm Kauṇā un Šauḷos ir iekḷautas Lietuvas nekustamo kultūras vērtību sarakstā. Agrīniem K. Reisona projektiem raksturīgs historisms, eklektisma elementi, «kiegeḷu stils», vēlākie projekti iezīmējas ar modernismam raksturīgu askētisko racionālismu, funkcionālismu, piemērošanos pie pilsētbūvnieciskā un kultūrvēsturiskā konteksta.

Atslēgas vārdi: Kārlis Reisons, Lietuvas arhitektūra, Kauṇa, Panevēža, Adelaida. 
Статья знакомит с профессиональной деятельностью литовского архитектора и инженера латышского происхождения Карлиса Рейсонса (Karolis Reisonas; 1894-1981) во второй половине его жизни - с 1930 года в Каунасе, Паневежисе и Аделаиде, и значением его работ в истории литовской архитектуры. К. Рейсонс был одним из самых выдающихся создателей современной литовской архитектуры XX века, и вместе с другими известными литовскими архитекторами сформировал особый стиль современной каунасской архитектуры межвоенного периода. К. Рейсонс является автором или соавтором представительских зданий в Шяуляе, Каунасе и других городах Литвы, а также в Риге и Аделаиде. Архитектор и инженер К. Рейсонс работал инженером в городе Шяуляе и заведующим Отделом муниципального строительства (1922-1930), директором Шяуляйского профессионального училища (1926), консультантом Литовской сельскохозяйственной камеры (1927-1928), руководителем Отдела строительства Каунасского самоуправления (1930-1938), инженером в Паневежисе (1940) и бюргермейстером (19411944). С 1949 года семья Рейсонсов проживала в Аделаиде, Австралия.

По его проектам в Литве были построены три памятника независимости Шяуляйский памятник независимости, постамент Каунасского памятника свободы и Каунасская Римско-католическая церковь Воскресения Христа. 14 из спроектированных им зданий в Каунасе и Шяуляе включены в список культурного наследия Литвы. Ранним проектам К. Рейсона присущи историзм, элементы эклектики, «кирпичный стиль», а более поздние проекты характеризуются строгим рационализмом, функционализмом, адаптацией к городскому строительству и культурноисторическим контекстом.

Ключевые слова: Карлис Рейсонс, литовская архитектура, Каунас, Паневежис, Аделаида. 